\title{
Minimally Invasive Treatment of Biventricular Hydrocephalus Caused by a Giant Basilar Apex Aneurysm via a Staged Combination of Endoscopy and Endovascular Embolization: A Case Report
}

\author{
Endoskopi ve Endovasküler Embolizasyonun Kademeli Kombinasyonu \\ Yoluyla Dev Baziller Apeks Anevrizmasının Neden Olduğu Biventriküler \\ Hidrosefalinin Minimal Invaziv Tedavisi: Bir Olgu Sunumu
}

Pradeep SETTY ${ }^{1}$, Andrey VOLKOV ${ }^{1}$, Boyd RICHARDS², Ryan BARRETT²

${ }^{1}$ St. John Providence Health System, Michigan State University, Department of Neurosurgery, Southfield, USA

${ }^{2}$ Michigan Spine and Brain Surgeons, Department of Neurosurgery, Southfield, USA

Corresponding Author: Pradeep SETTY / E-mail: drpsetty@gmail.com

\begin{abstract}
Biventricular hydrocephalus caused by a Giant Basilar Apex Aneurysm (GBAA) is a rare finding that presents unique and challenging treatment decisions. We report a case of GBAA causing a life-threatening biventricular hydrocephalus in which both the aneurysm and hydrocephalus were given definitive treatment through a staged, minimally invasive approach.

An obtunded 82-year-old male was found to have biventricular hydrocephalus caused by an unruptured GBAA obstructing the foramina of Monro. The patient was treated via staged, minimally invasive technique that first involved endoscopic fenestration of the septum pellucidum to create communication between the lateral ventricles. A programmable ventriculo-peritoneal shunt was then placed with a high-pressure setting. The patient was then loaded with dual anti-platelet therapy prior to undergoing endovascular coiling of the GBAA with adjacent stenting of the Posterior Cerebral Artery. He remained on dual anti-platelet therapy and the shunt setting was lowered at the bedside to treat the hydrocephalus. At 6-month follow up, the patient had returned to his cognitive baseline, speaking fluently and appropriately.

Biventricular hydrocephalus caused by a GBAA can successfully be treated in a minimally invasive fashion utilizing a combination of endoscopy and endovascular therapy, even when a stent-assisted coiling is needed.
\end{abstract}

KEYWORDS: Coil embolization, Endoscopy, Endovascular, Giant aneurysm, Obstructive hydrocephalus

öz

Dev Baziller Apeks Anevrizmasının (GBAA) neden olduğu biventriküler hidrosefali nadir bir bulgudur. Tedavi kararları eşsiz ve zordur. Hem anevrizma hem hidrosefalinin, minimal invaziv yaklaşımla kademeli olarak kesin tedavi edildiği; yaşamı tehdit edici bir biventriküler hidrosefaliye neden olan GBAA olgusu sunuldu.

Zihinsel olarak donuk, 82 yaşında bir erkekte, Monro foramenini tıkayan rüptüre olmamış bir GBAA nedeniyle biventriküler hidrosefali bulundu. Hasta kademeli, minimal invaziv bir teknikle tedavi edildi ve önce lateral ventriküller arasında geçiş oluşturmak üzere septum pellusidumun endoskopik fenestrasyonu yapıldı. Sonra yüksek basınçlı ortamda programlanabilir bir ventriküloperitoneal şant yerleştirildi. GBAA'ya endovasküler sarmal yerleştirme ve yanında posterior serebral artere stent konulması öncesinde hastaya ikili antitrombosit tedavi yüklendi. İkili antitrombosit tedaviye devam edildi ve hidrosefaliyi tedavi etmek üzere şant ayarı yatak yanında azaltıldı. 6 aylık takipte hasta kognitif olarak başlangıç durumuna dönmüştü ve akıcı ve uygun bir şekilde konuşuyordu.

GBAA'nın neden olduğu biventriküler hidrosefali, stent yardımlı sarmal yerleştirilmesi gerektiği zaman bile, endoskopi ve endovasküler tedavinin bir kombinasyonu kullanılarak minimal invaziv şekilde başarıyla tedavi edilebilir.

ANAHTAR SÖZCÜKLER: Sarmal embolizasyonu, Endoskopi, Endovasküler, Dev anevrizma, Obstrüktif hidrosefali

\section{INTRODUCTION}

Giant basilar apex aneurysms (GBAA) are a rare and unique pathology $(3,4,8,10)$. Despite a low rate of spontaneous rupture, a GBAA has the potential to cause potentially fatal obstructive hydrocephalus $(3,8,10,13,17,21,22)$. This generally occurs via direct compression of the third ventricle limiting the amount of cerebrospinal fluid (CSF) that can reach the cerebral aqueduct. As the aneurysm continues to grow, compression of one of both of the foramina of Monro can occur, discontinuing communication between the two 
lateral ventricles and causing a univentricular or, in our case, biventricular obstructive hydrocephalus. Treatment of the hydrocephalus alone can potentially increase the risk of GBAA rupture, as it may cause a sudden change in the intramural pressure surrounding the dome of then aneurysm. As a result, the GBAA needs to be secured prior to treatment of the hydrocephalus. Open clipping of a GBAA carries a high morbidity and endovascular coiling often times needs concurrent stent placement, requiring post-operative anti-platelet therapy, therefore eliminating the possibility of subsequent shunt placement. As a result, not only does this pathology requires multiple, staged procedures, but also an additional challenge is deciding the order in which these procedures will occur. We present our staged treatment scheme for a critically ill patient with biventricular hydrocephalus caused by a GBAA. To the author's knowledge this is the first report of this scenario in which both the hydrocephalus and aneurysm receive definitive and minimally invasive treatment.

\section{CASE REPORT}

\section{Presentation}

An 82-year-old male presented to our institution after being found unresponsive. His family stated that three months prior he had been fully functional and independent, however, he had been progressively declining since then. They noted, he had increasing confusion, gait instability, urinary incontinence, decrease in memory and progressive left-sided weakness. He had been taken to several other institutions where his pathology had been deemed untreatable and was subsequently placed in a nursing home. Prior to admission, he was found at his nursing home unresponsive and brought to our institution by EMS. On admission, the patient was comatose. His Glascow Coma Scale (GCS) was 7, as he was non-verbal, localizing to noxious stimuli in all extremities and not opening his eyes. His brainstem reflexes were intact.

\section{Imaging}

Computed Tomography (CT) of the head with and without contrast revealed obstruction of the foramina of Monro by a homogeneously enhancing mass that appeared to communicate with the basilar artery, causing obstructive hydrocephalus (Figure 1A, B). This radiologic finding was highly suspicious for a GBAA. The following day, CT angiography was performed and confirmed the presence of the previously suspected GBAA.

\section{Treatment}

The patient was first taken to the operating room where a right frontal endoscopic approach to the right lateral ventricle was performed. Here, the Foramen of Monro was visualized as well as the pulsating GBAA below the floor of the third ventricle (Figure 2A, B). The septum pellucidum was then identified and endoscopically fenestrated to create communication between the two lateral ventricles (Figure $3 A, B)$. Next, a programmable ventriculo-peritoneal shunt was placed with an initial high setting to minimize the amount of CSF drainage and as a result, limit the change in transmural pressure for the unsecured aneurysm. The patient remained intubated and returned to the ICU. He was then given loading doses of clopidogrel and aspirin and taken to the endovascular suite where he underwent coil embolization of the GBAA and left posterior cerebral artery stenting (Figure $4 A-D$. He remained on dual anti-platelet therapy post stent/ coiling. The following day, the shunt setting was changed at bedside to a low pressure so as to increase the amount of CSF drainage and provide treatment of the hydrocephalus. The patient was then extubated and remained hospitalized for five more days, during which his arousal, mentation,
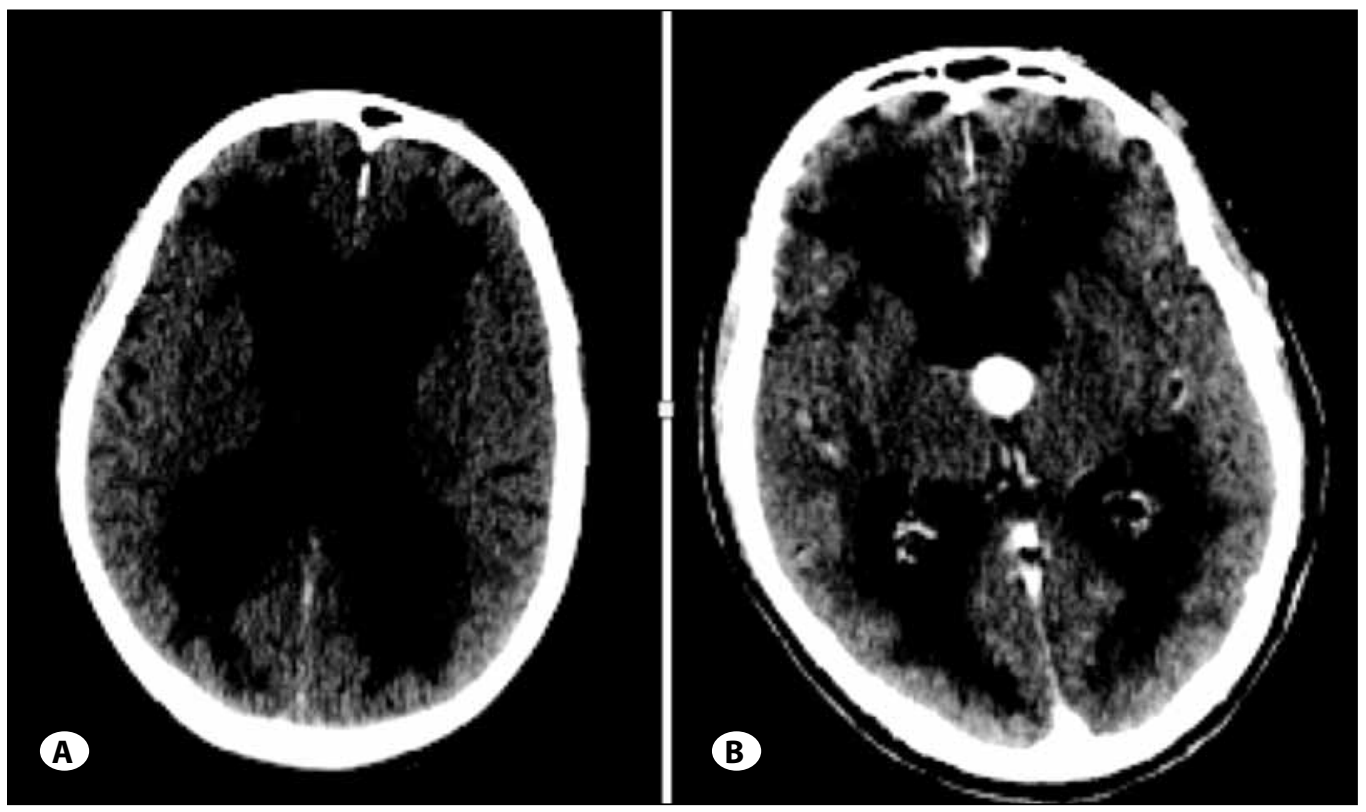

Figure 1:

A) Pre-Operative

CT Head without contrast demonstrates biventricular hydrocephalus.

B) Pre Operative CT Head with contrast demonstrates homogeneously enhancing mass at the $3^{\text {rd }}$ ventricle obstructing the foramen of Monro and causing biventricular hydrocephalus. 

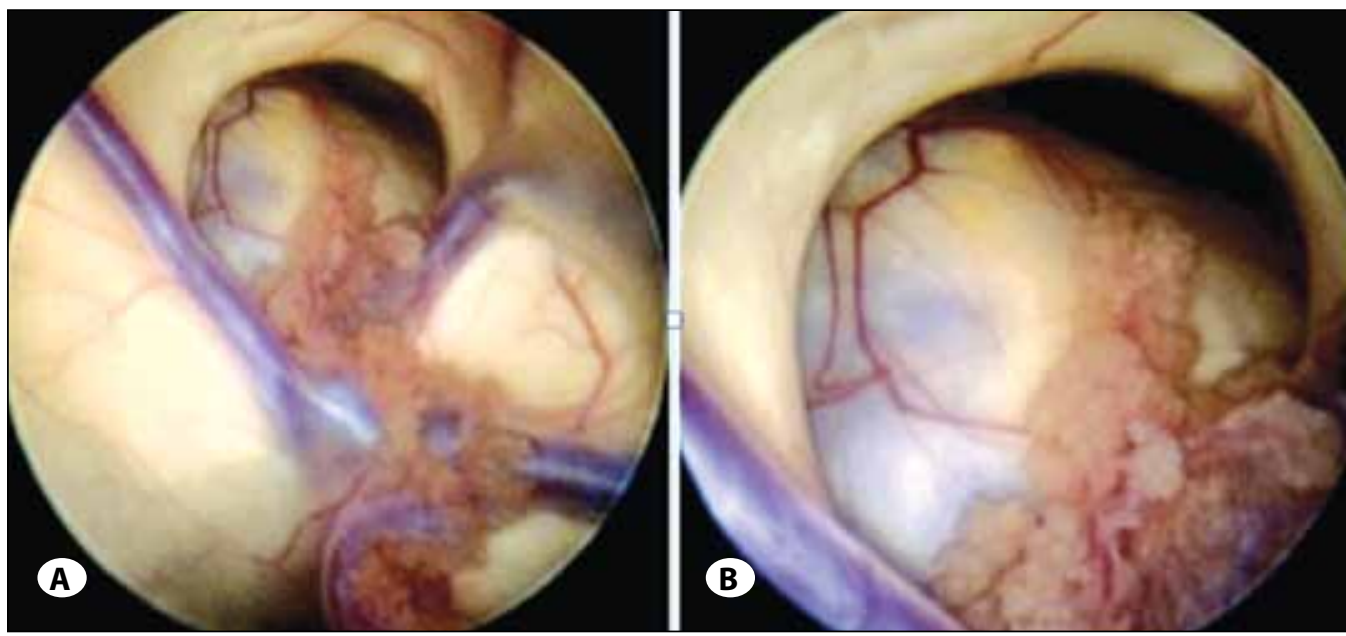

Figure 2: A) Intra-

operative distal view of the right foramen of Monro via endoscope. The septal and thalamostriate veins as well as the choroid plexus are visualized to assist in identifying the ventricle. B) Intra-operative proximal view of the right foramen of Monro via endoscope. A large pulsatile mass is seen compressing the $3^{\text {rd }}$ ventricle, likely the GBAA.
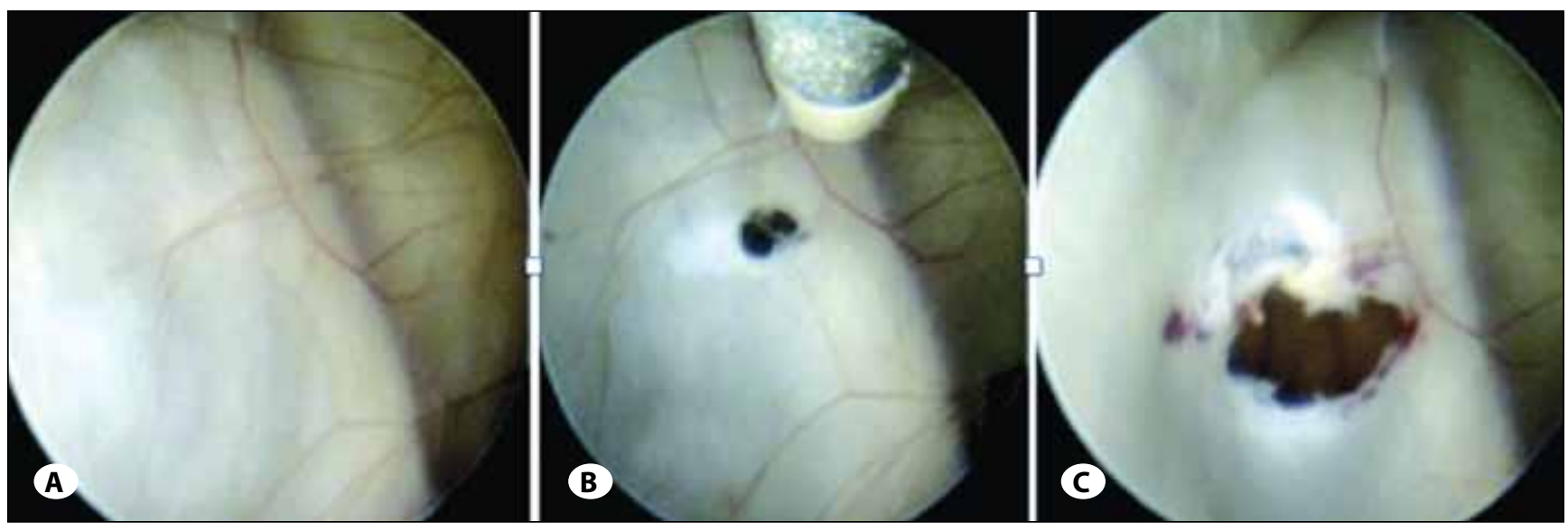

Figure 3: A) Intra-operative endoscopic view of septum pellucidum prior to fenestration. B) Intra-operative endoscopic view of septum pellucidum after initial perforation. C) Intra-operative endoscopic view of septum pellucidum post fenestration with CSF flowing through defect.

cognition and strength rapidly improved. Prior to discharge, he was awake, alert and oriented to person, place and time. His strength had returned back to his baseline and he was able to ambulate with moderate ataxia.

\section{Follow Up}

At 6-month follow-up, the patient had made dramatic improvement clinically and radiologicaly (Figure 5A, B). He was alert and fully oriented, able to converse fluently and appropriately. His family stated that he was not at his neurologic baseline in terms of functionality and cognition. His gait remained mildly ataxic but was able to ambulate with minimal assistance of a cane. He was now living independently and able to perform all tasks of daily living.

\section{DISCUSSION}

Isolated from one another, obstructive hydrocephalus and basilar apex aneurysms are relatively straightforward pathologies to treat. The presence of both of these pathologies together, while rare, creates an extremely difficult patient to treat. At our institution, endoscopic third ventriculostomy (ETV) remains the mainstay of treatment in the setting of isolated obstructive hydrocephalus. The ETV procedure has shown high rates of success by creating an alternative pathway for CSF to flow $(5,7,9,11,15)$. ETV, however, has a known potential complication of damaging the basilar artery due to the location of the area of fenestration at the floor of the third ventricle; this is especially true when a basilar apex aneurysm is present $(1,5,12,14,16,19)$. As a result, ETV is too dangerous of a procedure to perform in a patient with a GBAA.

Success with endoscopic fenestration of the septum pellucidum in the presence of unilateral hydrocephalus from a basilar apex aneurysm has been reported $(2,18,20)$. This technique, however, can only be performed when one of the foramen of Monro is patent as it allows for CSF from the obstructed ventricle to flow into the contralateral ventricle out of the contralateral foramen of Monro. Unfortunately, it has no role in biventricular obstructive hydrocephalus as neither foramen of Monro is patent. Placement of bilateral ventriculo- 
peritoneal shunts is also an option, however, this creates additional incisions, risks for infection and risks of malfunction. As a result, at our institution, in the setting of biventricular obstructive hydrocephalus in which the obstructing structure cannot be removed, we prefer to endoscopically fenestrate the septum pellucidum to create communication between the two lateral ventricles and through the same incision place a unilateral ventriculo-peritoneal shunt that is able to drain CSF from both lateral ventricles.

Further complicating this particular case was the fear of aneurysm rupture due to the potential drop in ICP and
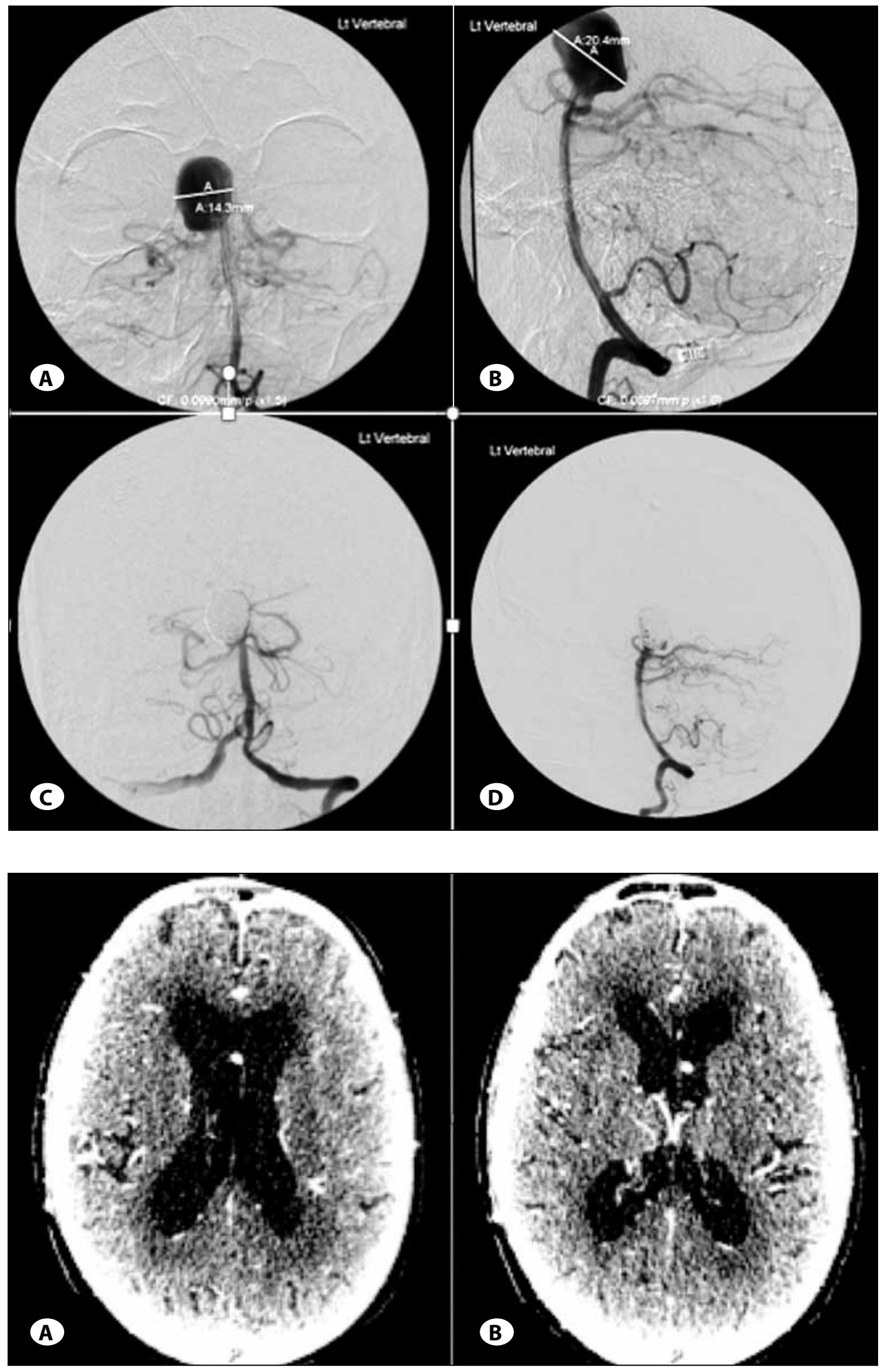

Figure 4: A) AP view of pre-coiling angiography demonstrating GBAA. B) Lateral view of pre-coiling angiography demonstrating GBAA. C) AP view of post-coiling angiography demonstrating embolization of GBAA. D) Lateral view of post-coiling angiography demonstrating embolization of GBAA.
Figure 5: A) 6-Month follow up CT Head demonstrated improved ventricular size with decreased trans-ependymal flow. Shunt catheter tip can be seen midline at the site of the septum pellucidum defect.

B) 6-Month follow up CT Head with shunt catheter tip shown in contralateral ventricle. 
transmural pressure that would be created by treating the hydrocephalus. As a rupture of the aneurysm in this setting would likely result in a fatal outcome, the aneurysm needed to be treated as well. In our institution, posterior circulation aneurysms are generally treated via endovascular coil embolization. Initially, it was felt as though the aneurysm should be secured prior to any treatment of the hydrocephalus, thereby significantly decreasing any risk of fatal rupture as ICP and transmural pressure decreases. However, upon studying the pre-operative CT Angiogram, it was concluded that stenting of the left posterior cerebral artery (PCA) was necessary in order to keep the vessel patent if the adjacent GBAA was coiled. This would necessitate dual anti-platelet therapy, aspirin and clopidogrel, to be continued for several months after the intervention, making any further surgery, such as placing a shunt, impossible. As the patient was already in critical condition, this was not an option. As a result, it was decided that the endoscopic fenestration of the septum pellucidum and shunt placement needed to precede securing the aneurysm.

In order to exercise control over the rate of ICP changes, a Strata II Programmable Valve (Medtronic, Minneapolis, MN) was used and set to its highest setting, $2.5(17 \mathrm{~cm}$ $\mathrm{H}_{2} \mathrm{O}$ ), in order to limit changes to the transmural pressure and maintain the wall integrity of the GBAA. While still not ideal, this allowed us to have appropriate mechanisms in place to treat the hydrocephalus while minimizing the risk of aneurysm rupture. Prior to endovascular coiling and stent placement, the patient needed to be loaded with antiplatelet therapy. As a result, we waited until post-operative day 3 before giving loading doses of aspirin and clopidogrel. The patient then went for endovascular stenting and coiling on post-operative day 4. Following successful coiling of the GBAA, confirmed by post-procedure angiography, the setting of the shunt valve was changed from 2.5 to 1.5 at the bedside, using the Strata II magnetic reprogrammer (Medtronic, Minneapolis, MN). This increased the rate of CSF drainage, allowing for appropriate treatment of the hydrocephalus. The patient did make significant improvement in his mental status and was discharged to a rehabilitation facility six days after endovascular coiling. At his 6-month follow up appointment, the patient was able to ambulate independently without assistance. He was also functioning independently and able to manage all of the daily tasks of living. In addition, his family stated that he had returned to his cognitive baseline.

This particular case presented a unique challenge. Ideally, ETV would be the procedure of choice in the absence of the increased risk of hemorrhage from the GBAA. Furthermore, we would have preferred to secure the aneurysm prior to treating the hydrocephalus to minimize the hemorrhage risk during shunt placement, however, the need for PCA stenting made this option impossible. Using a programmable shunt with fenestration of the septum pellucidum followed by endovascular stenting and coiling appeared to be the safest and most reliable option. Further complicating the situation was the patient's elderly age. Several other major institutions had already deemed his pathology as untreatable do to its complexity and the patient's age. His family, however, was extremely adamant about aggressive treatment due to his high baseline level of functionality. After reviewing the patient's history, physical exam and radiographic studies it was determined that his symptomatology was likely a result of the obstructive hydrocephalus, which is a commonly treated condition in patients of this age at our institution. As a result, a customized treatment plan was created and executed with an excellent overall outcome.

\section{CONCLUSION}

Giant basilar apex aneurysms, with resulting bilateral obstructive hydrocephalus, are a rare, but reported pathology. Treatment approaches can be especially challenging and need to be tailored specifically to each patient and their specific anatomy. A customized combination of endoscopy and endovascular therapy can allow for safe, effective and minimally invasive treatment of this unique pathology as was illustrated in our case.

\section{ACKNOWLEDGEMENTS}

Thank you to Dr. Beverly Walters, M.D. for continued support in assembling and editing this article.

\section{REFERENCES}

1. Abtin K, Thompson BG, Walker ML: Basilar artery perforation as a complication of endoscopic third ventriculostomy. Pediatric Neurosurg 28(1): 35-41, 1998

2. Aldana PR, Kestie JR, Brockmeyer DL, Walker ML: Results of endoscopic septal fenestration in the treatment of isolated ventricular hydrocephalus. Pediatr Neurosurg 38(6): 286-294, 2003

3. Borrie MJ, Campbell AJ, Caradoc-Davies TH: Obstructive hydrocephalus secondary to giant cerebral aneurysm in the elderly: Two case reports of functional improvement after ventricular shunting. J Am Geriatr Soc 33: 210-212, 1985

4. Bose B, Northrup B, Osterholm J: Giant basilar artery aneurysm presenting as a third ventricular tumor. Neurosurgery 13(6): 699-702,1983

5. Buxton N, Punt J: Cerebral infarction after neuroendoscopic third ventriculostomy: Case report. Neurosurgery 46:9991002,2000

6. Buxton N, Turner V, Ramli N, Vloeberghs M: Changes in third ventricular size with neuroendoscopic third ventriculostomy: A blind study. J Neurol Neurosurg Psychiatry 72: 385-387, 2002

7. Feng H, Huang G, Liao X, Fu K, Tan H, Pu H, Cheng Y, Liu W, Zhao $D$ : Endoscopic third ventriculostomy in the management of obstructive hydrocephalus: An outcome analysis. J Neurosurg 100: 626-633, 2004

8. Goetz C, Seifort V, Haubitz B: The foramen of monro-blockage caused by a giant aneurysm of the basilar artery: A case report and review of the literature. Neurochirurgia (Stuttg) 33(4):122-126, 1990 
9. Grunert $\mathrm{P}$, Charalampaki $\mathrm{P}$, Hopf N, Filippi R: The role of third ventriculostomy in the management of obstructive hydrocephalus. Minimally Invasive Neurosurgery 46(1):16-21, 2003

10. Hongo K, Morota N, Watabe T, Isobe M, Nakagawa H: Giant basilar bifurcation aneurysm presenting as third ventricular mass with unilateral obstructive hydrocephalus: Case report. J Clin Neurosci 8(1): 51-54, 2001

11. Hopf N, Grunert P, Fries G, Resch KD, Perneczky A: Endoscopic third ventriculostomy: Outcome analysis of 100 consecutive procedures. Neurosurgery 44: 795-806, 1999

12. Horowitz $M$, Albright $A L$, Jungeis $C$, Levy EL, Stevenson K: Endovascular management of a basilar artery false aneurysm secondary to endoscopic third ventriculostomy: Case report. Neurosurgery 49: 1461-1465, 2001

13. Ishibashi A, Yokokura Y, Kojima K, Abe T. Acute obstructive hydrocephalus due to an unruptured basilar bifurcation aneurysm associated with bilateral internal carotid occlusion: A case report. Kurume Med J 40(1): 21-25, 1993

14. Ishihara S, Kamikawa S, Suzuki C, Katoh H, Ross I, Tsuzuki N, Ahnuki A, Miyazawa T, Nawashiro H, Shima K: Neuroendoscopic identification of a basilar artery tip aneurysm in the third ventricle. J Neurosurg 96: 1138, 2002

15. Jones RFC, Stening WA, Brydon M: Endoscopic third ventriculostomy. Neurosurgery 26: 86-92, 1990
16. McLaughlin MR, Wahlig JB, Kaufman AM, Albright AL: Traumatic basilar aneurysm after endoscopic third ventriculostomy: Case report. Neurosurgery 41:1400-1404, 1997

17. Oertel JMK, Mondorf Y, Gaab MR: Endoscopic third ventriculostomy in obstructive hydrocephalus due to giant basilar artery aneurysm. J Neurosurg 110: 14-18, 2009

18. Oertel, JMK, Schroeder HWS, Gaab MR: Endoscopic stomy of the septum pellucidum: Indications, technique and results. Neurosurgery 64: 482-493, 2009

19. Schroeder HWS, Warzok RW, Assaf JA, Gaab MR: Fatal subarachnoid hemorrhage after endoscopic third ventriculostomy. J Neurosurg 90:153-155, 1999

20. Schroeder HWS, Oertel J, Gaab MR: Endoscopic treatment of cerebrospinal fluid pathway obstructions. Neurosurgery 60 Suppl 2: ONS44-ONS51, 2007

21. Stachura K, Libionka W, Moskala M: Neuroendoscopic third ventricostomy in the management of noncommunicating hydrocephalus secondary to giant basilar artery bifurcation aneurysm: Case report and review of literature. Neurol Neurochir Pol 42(3): 255-262, 2008

22. Watanabe A, Imamura K, Ishil R: Endosaccular aneurysm occlusion with guglielmi detachable coils for obstructive hydrocephalus caused by a large basilar tip aneurysm. J Neurosurg 91: 675-678, 1999 